\title{
Deus Salve Casa Santa, Morada de Foliões. Rito, Memória e Performance Identitária em uma Festa Rural no Estado de São Paulo ${ }^{1}$
}

José Rogério Lopes Este artigo aborda algumas transformações ritualísticas ocorridas nas festividades

(Unisinos) religiosas rurais, no Brasil, devido aos processos de migração e de modernização da agricultura. $O$ pano de fundo dessa abordagem é um caso etnográfico estudado pelo autor, desde 1987, no bairro rural Santa Cruz do Rio Abaixo, no município de São Luiz do Paraitinga, situado no cone leste do estado de São Paulo, em meio à Serra do Mar.

Trata-se, aqui, de caracterizar os processos de reestruturação ritual que ocorreram em um contexto de relações entre mudança e tradição, de forma a apontar as potencialidades desta última como matriz para novos arranjos rituais, ao mesmo tempo em que se busca analisar em situação a emergência de novas mediações dos processos identitários, no contexto analisado.

\section{O CONTEXTO DA ANÁLISE}

O bairro rural Santa Cruz do Rio Abaixo surge de uma Sesmaria doada em 1777 ao colono e povoador de São Luiz do Paraitinga (SP), Antônio Domingues de Castro, pelo Capitão General da Capitania de São Paulo, Martim Lopes Lobo de Saldanha. Com o falecimento do donatário, no início do século XIX, seu filho Manoel Domingues de Castro herdou quase a totalidade das terras concedidas pelo governo a seu pai. Tendo por sua vez Manoel falecido no ano de 1839, em seu inventário coube uma meação que foi recebida pelo herdeiro Bento Domingues de Castro: no seu pagamento recebeu " 250 braças de testada por hum quarto de sertão no local chamado Logradouro" (atual bairro Santa Cruz do Rio Abaixo), quarenta alqueires de algodão, escravos e semoventes.

Com o advento da lavoura cafeeira, nos anos 40 do mesmo século, a Vila de São Luiz vivenciou um período de prosperidade econômica. A produção de café fez aumentar o número de escravos. 
Contudo, a fase de opulência de algumas famílias da região não durou mais do que algumas décadas e, já na virada do século, a economia do município caracterizava-se muito mais pela produção de gêneros alimentícios básicos, a exemplo do milho, feijão e mandioca, do que como produtora concorrente de café no Vale.

A decadência econômica se consolidou definitivamente a partir dos anos 20 do século XX, com o deslocamento da produção de café para a região Oeste do Estado de São Paulo e o esgotamento do solo, em virtude da forma predatória de cultivo empregada. As grandes fazendas de monocultura e escravistas fragmentaram-se, em um primeiro momento devido ao sistema da herança divisível; depois foram os próprios herdeiros que se incumbiram de negociar a sua parte.

A partir das décadas 1930 e 40, o valor comercial das terras em São Luiz do Paraitinga baixou. Isso atraiu compradores de fora, em sua maioria sujeitos do Sul de Minas Gerais. Esses sujeitos devassaram os cafezais remanescentes e derrubaram as matas ainda intactas, introduzindo e disseminando a pecuária.

No início dos anos 1950, foi construída pelos migrantes mineiros, por força de sua devoção, uma capela em homenagem à Santa Cruz, localizada em um terreno doado por um fazendeiro. Próximo à capela foram construídas algumas casas, que posteriormente constituíram o arraial de Santa Cruz do Rio Abaixo.

Os migrantes mineiros passaram a reproduzir, na região, festas relacionadas às suas manifestações devocionais, legitimando um campo de condutas religiosas populares. Desde o primeiro migrante a se instalar no bairro, em 1950, começou a se construir a capela de Santa Cruz, que se confundiu com um processo migratório familiar. Após a conclusão da capela, tornou-se esta a principal referência comunitária, como elemento agregador do grupo familiar original, das famílias que se desdobraram deste e das demais famílias que vieram se instalar no bairro, fazendo surgir oficialmente as festas em homenagem aos Santos Reis (em janeiro ou fevereiro) e à Santa Cruz (em maio).

Segundo depoimento de Adolfo Leite, Mestre da tradicional Folia de Reis do bairro, a primeira festa de Santos Reis ocorreu no ano de 1957, um ano antes da sua chegada no local. Sua chegada foi importante porque ele já era Mestre de uma Folia existente na antiga região de origem do grupo (Pouso Alto, MG). Dessa forma, sua presença possibilitou constituir a Folia de Reis, que é o elemento central da produção do ciclo festivo devocional.

Entre os aspectos centrais da agregação promovida pela festa estava o fato de que a Folia era composta por três primos (Adolfo Leite, Zé Leite e João Leite), o cunhado da mulher de Zé Leite (Vicente Gonçalves) e um filho de João Leite (João). Simultaneamente, seu Adolfo, seu Zé Leite e seu Vicente eram também reconhecidos na comunidade pelos carismas que explicitavam: o primeiro podia ser caracterizado como o xamã local; o segundo era o animador comunitário e o terceiro era o sujeito da ordem².

As festas de Santos Reis foram promovidas e organizadas pelos migrantes mineiros, que mantiveram os seus costumes e tradições até o ano de 1996, ininterruptamente. Por todos esses anos, o grupo familiar instalado no bairro de Santa Cruz do Rio Abaixo reproduzia uma conduta devocional estruturada em moldes tradicionais. A Folia percorria, por várias noites do mês de dezembro até 2 de fevereiro - dia de Nossa Senhora das Candeias, ou da Candelária - as casas do bairro e redondezas, realizando cantos e rezas solenes na frente dos presépios.

Simultaneamente, a peregrinação devocional arrecadava doações diversas que serviam à realização da festa que encerrava o ciclo devocional, sendo esta de responsabilidade de um casal de festeiros escolhidos anualmente, entre os sujeitos do bairro. A responsabilidade dos festeiros estendia-se da organização e manutenção da peregrinação dos Foliões até a realização da festa, o que implicava recepcionar os devotos em sua propriedade. 
Dessa forma, a festa tornou-se volante, proporcionando uma integração das famílias do bairro em torno de um ritual sazonal, que produzia um modelo devocional extensivamente orientado pela Folia e intensivamente realizado pelo encontro da comunidade. Em outras palavras, a Folia articulava uma rede de relações que a festa punha em dança, ritualizada no espaço doméstico.

As originalidades desse modelo manifestavam-se, sobretudo, no cerimonial de encerramento do ciclo devocional de Santos Reis do bairro, nos aspectos reproduzidos na espacialização da festa e na representação dos festeiros atuais e novos. No primeiro, acentua-se a chegada da Folia no espaço festivo doméstico, que tem de parar diante de três arcos sucessivamente preparados no seu caminho, sob os quais o Mestre cantava versos específicos de devoção aos Santos Reis e de saudação à comunidade de devotos presentes na festa e aos festeiros. No segundo, acentua-se o fato dos Festeiros escolhidos para a próxima festa serem coroados e representados por um casal de crianças, geralmente filhos do casal que se responsabilizava efetivamente pela festa. Na passagem da Coroa de Reis, entretanto, os festeiros responsáveis de um determinado ano eram colocados no centro do cerimonial (tal representação sintetiza a renovação e o envelhecimento do ciclo devocional, em uma dupla simbolização: ao coroarem os festeiros, estes também personificavam os Santos Reis, motivo da devoção).

O ritual de encerramento era sempre orientado pela Folia que, através de seu Mestre, entoava um conjunto de versos que mesclava a história da festa e da devoção, mas também orientava e justificava a cerimônia de passagem da coroa dos Reis Velhos para os Novos, que era realizada por dois bastiões (palhaços) que acompanhavam a Folia. Após a finalização do ritual de passagem da coroa dos Reis-festeiros, ocorria distribuição de doces e um animado forró, que se estendia até a madrugada.

Ocorre que o falecimento de Zé Leite, em 1990, deixou entristecido o Mestre, Adolfo Leite, que não saiu com a Folia em 1990 e 91, retornando somente em 1992. Após o falecimento do próprio seu Adolfo, em 1993, seu primo João Leite tomou a frente da Folia, dirigindo-a até 1996. A inabilidade do novo Mestre, entretanto, aliada ao falecimento de outro membro antigo da Folia (seu Vicente Gonçalves), desmotivou a realização comunitária da festa, que ficou sem acontecer entre os anos de 1997 e 98.

Em 1999, por iniciativa dos familiares dos antigos foliões, a Festa de Reis foi retomada, mas sem a Folia. A decisão da realização da festa e sua preparação ocorreram em um prazo curto, de dois meses de antecedência. Como não havia Folia, o ciclo festivo-devocional reduziu-se a uma única ocasião e, como também não havia festeiro escolhido anteriormente, a festa realizou-se no espaço em frente à capela do bairro, "Ionge das famílias". O caráter inusitado desta festa é o motivo da descrição que segue. Alguns aspectos do movimento da festa serão enfatizados para uma análise posterior.

\section{A FESTA DE 1999}

Dia 23 de janeiro. Cheguei ao bairro às 16h20, pela estrada que o corta. Em frente à capela de Santa Cruz, um rancho improvisado de lona com várias pessoas. No campo de futebol, os times se preparavam para um jogo. As pessoas às portas das casas conversavam e esperavam, comentavam o movimento e a reza que estava sendo realizada na pequena capela no alto da vila. 
Em frente à capela, um carro de som amplificava a reza e o sermão que o ministro da eucaristia fazia para as pessoas da festa. O sermão falava enfaticamente de sexo, da disseminação de drogas entre os adolescentes, da "violência descabida e da falta de fé no mundo". Temas seculares e urbanos, num canto isolado da região. $O$ culto seguia e, na preleção para introduzir o Pai-nosso, o ministro da eucaristia comentava: "Vamos fazer uma corrente, mas não uma corrente feiticeira; não uma corrente supersticiosa, mas uma corrente de louvor em nome do Pai, Deus todo poderoso".

Percebi um descompasso entre as práticas religiosas e a própria organização da festa. A ausência do padre dispersou as pessoas presentes no local ${ }^{3}$.

Não foi difícil localizar os do lugar: velhos, ficavam à margem, conversando com outros; jovens, estavam se movendo e organizando a festa, de um lado para outro, ou lhe dando vida.

Não foi difícil também perceber os de fora: velhos, buscavam conhecidos para conversar; jovens, ficavam parados junto do carro de som, sem camisa quando homens, ou sentados com uma latinha de cerveja na mão.

A roupa é um detalhe que se perdeu entre os jovens, mas é característica entre os adultos e velhos do bairro: o chapéu é um ícone do homem rural, que se compõe indistintamente com o rosto enrugado e o pequeno bigode, sempre aparado.

A Festa de Reis raramente acontecia na vila, como hoje. Antes, era costume acontecer nos bairros rurais, em terras dos Reis festeiros. Como as casas das pessoas situam-se em locais distantes da vila, esta era sempre um local de passagem, caracterizando o movimento dos sujeitos, mas não o lugar central do evento.

A centralidade que a capela assumiu esse ano acompanha-se de outra mudança. Antes, a distribuição dos doces era feita após a chegada e a apresentação da Folia - sempre em abundância, como ainda acontece. Esse ano, desde a tarde as pessoas aglomeravam-se em torno das doceiras, carregando as quatro variedades de doces (de abóbora, batata-doce, leite e arroz-doce) em vasilhas, para comê-los parcimoniosamente durante trinta dias e, assim, obter a proteção dos Santos Reis.

A festa na vila favoreceu a liberação dos costumes, já que não estávamos em terras de família. Via-se essa liberação nas barracas de cerveja e pinga, nos pequenos e provocativos shorts das adolescentes bonitas que ficavam desfilando pela festa, no "som mecânico" e nas demais atividades profanas que concorriam com o motivo da festa: os Santos Reis ficaram isolados no presépio montado na pequena capela ou na bandeira da Folia, guardada num pequeno aposento atrás da barraca da cerveja.

Havia uma Folia no local, da cidade de São Luiz do Paraitinga, convidada para cantar no presépio, mas seus foliões também estavam dispersos na festa. Somente eram reconhecidos pela camisa xadrez branco e vermelha e a calça preta.

A festa deste ano prometia, em seu cartaz, um encontro de Folias da região, mas que não se cumpriu. Porém, eu parecia ser um dos poucos descontentes com a ausência de outras Folias. A única Folia a se apresentar foi a de São Luiz do Paraitinga. Composta de doze membros (Mestre, contra-mestre, contralto, seis instrumentistas, dois palhaços e o carregador da bandeira), mas com um repertório de cantorias restrito, a Folia cantou no presépio dentro da igreja, à tarde, por cerca de vinte minutos e, depois, no rancho dos doces, paras as doceiras, por cerca de mais vinte. 
Após a apresentação dessa única Folia, todos os presentes se dispersaram novamente e começou um torneio de laço de novilha, que tinha um locutor que berrava intempestivamente, até a noite, tendo por fundo musical canções sertanejas e country, estas mais presentes.

Pela festa, os organizadores esbravejavam com alguns sujeitos seu descontentamento pela ausência das outras Folias, explicando a todos, após, os motivos que ouviram dos Mestres: em geral, conflitos havidos entre os componentes durante o percurso entre o Natal e o Dia de Reis. Outros, porém, comentavam que esta era "a primeira vez que a festa se abre para Folias de fora do bairro", o que seria causado pelo fato da Folia local ter "acabado".

Entre os acontecimentos da festa, uma fotógrafa de São Paulo registrava aspectos mais tradicionais e pitorescos, as figuras da Folia e outras, buscando ângulos de efeitos diversos. O que ela encontrava? Alguma plasticidade, várias incertezas.

Em princípio, tudo parecia estar muito descaracterizado, sem referências como as observadas até alguns anos atrás. Andando pela festa, as pessoas pareciam buscar coisas que não encontravam. Porém, observando de longe os lugares da festa, percebia-se que o cálculo dos acontecimentos era outro. As referências estavam cruzadas, sendo irradiadas desde onde as pessoas do lugar estavam.

Junto às doceiras, encontravam-se Dona Cida, viúva de Zé Leite, e sua filha Madalena. Madalena relatoume que Dona Cida teve "um problema nas pernas" e estava em uma cadeira de rodas. Animada, vivia todos os momentos da festa com intensidade, cercada de pessoas e familiares que a reverenciavam. Ela era, então, a referência mais ancestral do grupo familiar que manteve a Folia durante décadas.

Dona Cida e sua filha se fixaram perto dos doces, durante toda a tarde. Tornava-se mesmo difícil saber se estavam lá porque as pessoas iam pegar os doces, ou se as pessoas iam pegar os doces porque elas estavam lá.

Às vinte horas, o carro de som anunciou a cerimônia dos Reis festeiros. Um casal de adolescentes com coroas improvisadas e simples sentou-se apressadamente em um banco, representando os Reis do ano. Os palhaços os retiraram e os levaram para o fundo da festa, onde deviam aguardar.

Embaixo da lona improvisada em rancho, ao lado do carro de som, João, filho de João Leite e genro de Dona Cida, junto de seu João Santos (últimos remanescentes da Folia do bairro) e dois palhaços se preparavam. João carregava um tambor e seu João Santos um pandeiro. De repente, o carro de som começou tocar uma fita cassete com a gravação da cerimônia de coroação cantada pela Folia original do bairro, feita há dez anos, e incompleta.

A festa passou a girar em torno da música, em alguns momentos inaudível, mas solene. A memória do local estava naquelas vozes gravadas. A fita era tratada como uma relíquia (de repente, percebi que era possuidor de algumas delas e me emocionei, ouvindo a voz de mestre Adolfo).

Imaginei por momentos o itinerário da Folia pelas casas do bairro, durante o ciclo de Natal, e como ela chegava festivamente ao local da festa, sendo esperada por todos. Nesse ano, a Folia não teve itinerário, surgindo de uma fita, virtualmente.

Dona Cida se aproximou do local, trazida pelas filhas e motivada pelo som tão seu conhecido, e virou referência central da cerimônia. Palhaços primeiro e, depois, amigos e outros parentes, aproximavam-se, tocavam 
e abraçavam-na sucessivamente. Ela se colocou com a cadeira ao lado do carro de som, com as filhas à sua volta, e apreciou a cerimônia até o fim. A memória passara agora para sua figura, olhada por todos. À medida que a cerimônia se desenvolvia, dramatizada pelos palhaços, pelos adolescentes e, ao final, por duas crianças que representavam os Reis novos - novos festeiros, do ano 2000, crianças mais jovens que suas predecessoras -, as atenções transitavam entre a música, Dona Cida e suas filhas, os casais de Reis e os membros de uma "folia em playback". Sem dúvida, ali se formava uma síntese na e da memória local, em uma primeira inversão de elementos estruturais e anti-estruturais do ritual..

João e seu João Santos mostraram evidentes dificuldades em acompanhar o som ruim da fita da Folia, seja cantando, seja tocando os instrumentos que carregavam. Em compensação, os palhaços realizavam suas tarefas no ritual com desenvoltura, mostrando que conheciam bem a seqüência das ordens emitidas pelo Mestre, mesmo sem ouvi-las claramente.

Aos poucos, outros sujeitos locais começaram a arriscar cantar alguns dos versos já tão ouvidos antes, até o ponto em que a fita somente atuava como uma batuta de maestro, fazendo convergir as memórias individuais para um canto coletivo, embora difuso e tímido.

A performance dos palhaços ${ }^{4}$ foi essencial para essa convergência dos traços que permitem à memória local se enformar novamente. Mais essencial, talvez, tenha sido o fato de que o mais dramático dos palhaços (Ditão Virgílio) era um dos sobrinhos de Dona Cida e do falecido Zé Leite. Ele já estava vestido de palhaço e chamando a atenção dos participantes desde pelo menos duas horas antes da cerimônia de coroação.

$\mathrm{Na}$ cerimônia, ele conduzia o outro palhaço na troca das coroas e metaforizava, através da dança, a importância dos elementos da memória local, descritos acima. Indo em direção às crianças, fazendo saudações; ajoelhando-se em frente a Dona Cida e beijando-a formalmente no rosto e nas mãos; cercando a "Folia" e sua bandeira e rodeando a si próprio e ao companheiro; fazendo reverências aos casais de Reis festeiros velhos e novos; aproximando-se do pessoal que assistia e incitando-os ingenuamente; enfim, indicando e envolvendo todos os presentes, o palhaço anunciava para um inconsciente atento os traços que compóem o fato que ali se produzia: a memória local se refazendo, pelos fragmentos do que já foi. Nesse sentido, o palhaço assumiu-se como performer (Silva 2005), gerando uma interação com os espectadores e produzindo um "espelho mágico" (Schechner apud Silva 2005: 59) comunitário.

Nada mais exemplar dessa catarse que os discursos de encerramento da festa, feitos pelo casal de organizadores: Reinaldo, o festeiro, alegremente agradeceu a todos e exaltou a beleza de uma festa "que pode voltar a ser tão bonita quanto no tempo da Folia". Lúcia, a festeira, agradeceu também a todos, fez algumas menções ao caráter religioso da festa, à devoção aos Santos Reis, e encerrou lembrando o - e se desculpando pelo - caráter improvisado da cerimônia de coroação, “já que não temos mais a grandiosa Folia do bairro, tão bonita, que tivemos no passado. Foi muito bom e importante, por isso, a fita que o João gravou".

Acabou a "festa sagrada" e começou um forró. Dona Cida e as filhas se deslocaram para um canto perto da igreja e ficaram conversando e observando a festa. Os "foliões" guardaram os instrumentos e os palhaços as roupas, passando a confundir-se com as demais pessoas da festa, que aos poucos iam embora. 
Um primeiro aspecto a considerar está no deslocamento da festa do espaço familiar para o coletivo, em frente à capela do bairro, e a redução do ciclo festivo devocional a uma única ocasião. Mudança radical em um ciclo festivo devocional que tinha por tradição estruturar e reforçar uma rede de relações locais e comunitárias (Brandão 1981).

Tal mudança parece fortemente influenciada pela dissolução da Folia, que ocasionou a interrupção da peregrinação, da festa e da escolha dos festeiros. A retomada da motivação pela sua realização, dessa forma, pareceu não encontrar outro locus que não fosse o espaço coletivamente reconhecido como próprio do grupo, que se construiu juntamente com o projeto de instalação das famílias no lugar.

Tratar-se-ia de uma tentativa de reintegração das famílias, tanto das pessoas que continuam no lugar, quanto daquelas que se mudaram, em torno do resgate de uma tradição interrompida? Não à toa, alguns dos filhos dos antigos foliões, que incentivaram o retorno da festa, moram nas cidades próximas, onde trabalham e de onde vêm regularmente visitar as famílias.

A influência desses familiares distantes, de presença sazonal no bairro, produziu um movimento que se concentrou na figura de um casal de jovens primos, que se assumiram como festeiros do ano: Reinaldo e Lúcia. Segundo depoimento dos mesmos, a "intenção da festa era trazer o povo para comemorar e tirar um festeiro para o próximo ano". Como a Folia local se dissolveu, os festeiros buscaram apoio da prefeitura do município para realizar um encontro de Folias de Reis na festa, que "seria um atrativo a mais para chamar o povo".

Assumindo a responsabilidade pela festa, o casal encomendou quinhentos cartazes para fazer divulgação nos bairros e nas cidades próximos. Foi a primeira e última vez que a festa foi divulgada assim, uma vez que, nesse ano, a Folia não peregrinou. Também organizaram sozinhos a infraestrutura da mesma, desde a coleta de doações para os doces e leilão, até os contatos que permitiram a contratação do equipamento de som.

Em princípio, o equipamento de som serviria para reproduzir a fita com a gravação da Folia do bairro, idéia de Lúcia, que justificava: "assim, podíamos fazer o passamento da coroa, que sempre foi o ponto alto da festa. Não tem Mestre de Folia na região que saiba cantar o passamento da coroa, só os velhos da Folia daqui é que faziam, que é Folia de Reis mineira. Na paulista, não tem disso ${ }^{5}$. O João, genro do Zé Leite, tinha uma fita que ele gravou, então tocamos ela".

Vê-se, aqui, um conjunto de intencionalidades a mover os acontecimentos da festividade para uma convergência local: reviver uma tradição. Entretanto, a realização da festa se deu sobre uma abertura da tradição a influências que se situam fora do âmbito de controle da comunidade devocional, o que implicou a necessidade de trocar os protagonistas que orientam os rituais festivos devocionais.

Esse segundo aspecto pode ser destacado no movimento dos elementos que centralizam a memória local: a fita gravada, os familiares dos antigos foliões e o ritual ordenado pelos palhaços. Supõe-se que a ausência da Folia deslocou a centralidade estrutural do ritual (fixada no Mestre) para os elementos secundários, ou anti-estruturais (sobretudo, os periféricos, como os palhaços e os familiares ${ }^{6}$ ), atribuindo à memória um papel importante, cristalizado nas pessoas e nos discursos. 
Uma vez que a Folia estruturava a centralidade do ritual, ordenando a performance devocional, sua ausência reduziu a devoção que ela deveria orientar a ela própria. A ausência da mediação presentificada pela Folia fez com que sua falta fosse confundida com a própria devoção, ou que se sobredeterminasse a esta, comunalmente. Nesse sentido, a tradição revivida sintetiza a finalidade da mediação devocional aos Santos Reis, em um simulacro de ritual, atualizado pela memória coletiva?.

Esse movimento da memória mostrou variar entre relações inconsciente ou conscientemente motivadas. A atração social causada pela presença dos familiares dos antigos foliões sugere um resgate inconsciente da tradição da Folia, que emergiu em vários momentos da festa. Somente no ritual, entretanto, essa atração explicitou a ausência da Folia, quando resgatada conscientemente pela performance do palhaço, tendo o som da fita por fundo musical.

Tal suposição assenta-se no fato de que havia "outra" Folia na festa (que, aliás, fez a saudação ao presépio). Os familiares optaram, contudo, em reproduzir um ritual tradicional e organicamente ligado à devoção do grupo, mesmo que de forma precária. Essa opção parece evocar a própria "natureza"§ da festa e da devoção.

Essa síntese percorreria e estruturaria as motivações devocionais do ciclo de Santos Reis, no bairro, durante os próximos anos. Do re-nascimento da Folia, parecia surgir um aviso de resistência cultural, como uma re-descoberta de si, do grupo: “o mesmo, em si mesmo insistindo, em si mesmo pousa" (Parmênides).

Porém, a síntese dessa memória coletiva foi produzida sobre fragmentos da tradição, fato possível pela abertura da própria tradição a influências que se situam fora do âmbito de controle da comunidade.

Nesse processo, os jovens organizadores tiveram que negociar as intencionalidades locais (o lugar da festa, os padrões de sociabilidade e a própria memória local) com agentes externos, representantes de outros contextos de trocas materiais e simbólicas: comerciantes locais, agenciadores culturais (fotógrafos, proprietários de equipamento de som, outras Folias de Reis), representantes eclesiásticos leigos, agentes do governo local ${ }^{9}$.

Simultaneamente, a experiência das novas gerações de sujeitos locais, marcada por influências urbanas crescentes, interferiu na reprodução do imaginário local, deslocando e misturando as escalas das representações produzidas entre a identidade, a cultura e o lugar.

Essas novas "presenças" iriam se explicitar nas festas dos anos seguintes, de forma mais acabada, compondo um quadro de manifestações híbridas em torno de uma pequena narrativa identitária.

Assim é que, em 2000, a festa se realizou em um sítio do bairro, com uma Folia formada pelos dois remanescentes da original, mais alguns integrantes recrutados entre os jovens descendentes dos antigos foliões - um deles exerceu o papel de Mestre. A participação da Folia resumiu-se à festa e ao ritual de passagem da coroa dos Reis Festeiros, cantando versos decorados da audição da fita gravada por João, complementada por outra fita resgatada pelos familiares. A estratégia de reposição do ritual, dessa forma, manifestou uma potencialidade ampliada pelo uso da técnica de gravação, acessível à própria comunidade por um trabalho de investigação local e difuso, mas eficaz para as finalidades do grupo, de organização dos fragmentos da memória.

Contudo, como esse trabalho foi efetivado sem a mediação dos autores culturais tradicionais, detentores do conhecimento estruturado nas grandes narrativas que fundaram o imaginário local, a estratégia de reposição do ritual agregou outros instrumentos do pensamento, que permitiram unificar tais fragmentos. 
Já na festa ocorrida em 2001, o ciclo festivo devocional foi revivido em sua completude: a Folia peregrinou pelo bairro (embora só nos finais de semana) e o ritual da festa foi rememorado em sua espacialização e participação comunitária. Nesse contexto, a síntese da memória coletiva esboçada na festa de 1999 atingiu seu ápice, completando o processo de substituição da centralidade da devoção, que colocou lado a lado a devoção aos Santos Reis e o culto aos antepassados (os antigos foliões).

\section{A FESTA DE 2001}

Dia 03 de fevereiro. Chegamos de carro ao local da festa, por volta do meio dia. A estrada vazia e mal conservada já anunciava o esvaziamento da festa. No sítio de seu João Santos, próximo da vila do bairro, alguns parentes jogavam truco embaixo de um rancho de bambu e plástico preto, montado no terreiro da casa.

No fundo do rancho, um bar foi improvisado, com dois freezers, onde crianças bebiam refrigerantes em lata. Do mesmo bar, um aparelho de som lançava músicas sertanejas, estilo country.

Nenhum movimento que lembrasse a agitação das primeiras festas que freqüentei no bairro, desde 1987. Naquelas, logo pela manhã as casas já estavam cheias de parentes e amigos, servindo almoço para quem chegava. A festa, propriamente dita, era sempre antecipada por ciclos de visitas que faziam entre si os sujeitos do lugar - os que ficavam morando no bairro e os que se foram em busca de emprego, por casamento ou estudo e, nesse período, retornavam momentaneamente.

As roupas "urbanas" já não sugeriam um estilo "rústico" ou camponês, mas sim, um grupo de parentes passando o fim de semana num sítio. Os agrupamentos eram motivados pelo truco e não pela conversa sobre os afazeres de lavrador ou os serviços da casa, a criação ou os consertos das cercas.

A exceção era um jovem - filho de seu João - com síndrome de Down, que parecia o único ansioso para o início da festa, além dos pesquisadores.

Depois do almoço (dos familiares) alguns poucos adultos começaram a preparar os arcos de bambu que enfeitaram a entrada da propriedade e por onde passaram os foliões, anunciando em cantorias a sua chegada.

Aos poucos, começavam a chegar as pessoas conhecidas. O primeiro é Ditão Virgílio, antigo palhaço da Folia, expert em conduzir as cerimônias ditadas pelos foliões. Anunciou que a Folia devia sair da casa, no começo da tarde, para cantar em algumas moradias não visitadas.

Uma hora e meia depois de nossa chegada, e de muita cara de interesse, Dona Maria, a esposa do festeiro, convidou-nos a almoçar. Depois, mostrou orgulhosa os latões cheios de doces, "para distribuir ao povo".

Saímos da casa e as pessoas estavam ocupadas em decorar a festa: flores nos arcos, máscaras, bandeirinhas e a bandeira da Folia ${ }^{10}$, que foi pregada abaixo de uma janela, virada para o rancho da festa. Ao lado, foi colocado um quadro com foto da antiga Folia se apresentando em São Luiz do Paraitinga, onde figuravam seu Adolfo, seu Zé Leite e seu João Leite, velhos mestres da formação original, que animaram por anos a festa de Santos Reis no bairro.

Na casa, duas moças da família decoravam os chapéus que os palhaços usariam na festa. 
Seu Luiz (folião) e Ditão (palhaço) se aproximaram da foto da Folia e trocaram impressões. Depois, ficaram olhando a bandeira por algum tempo. Como outros sujeitos que foram chegando, pareciam rezar em frente da bandeira e, ao final, fizeram o sinal da cruz.

Dentro da casa, as moças estavam agora passando o uniforme dos foliões.

Às duas horas, o sol reapareceu, afugentando nuvens de chuva que ameaçavam a festa. Agora, o movimento das mulheres começara a se especializar: a mesa dos doces começou a ser preparada por algumas, os detalhes da decoração foram cuidados por outras e a limpeza do terreiro pelas adolescentes.

Começaram a espocar os rojões, anunciando a festa e a chegada de alguns visitantes de outro bairro. De um cômodo da casa saíram grandes caixas acústicas, que começaram a amplificar as músicas sertanejas.

Os preparativos foram se finalizando e, às 16 horas, começou uma sessão de axé-music. Entre memórias e visões do presente, viam-se as meninas ensaiando, em grupo, as coreografias didaticamente cantadas pelos grupos musicais como "É o Tchan".

Novos rojões anunciaram a chegada de três kombis da prefeitura, trazendo as "Folias de fora", ou "da cidade", como falavam os moradores, que participariam da festa: Folia do Alto do Cruzeiro, Folia de São Luiz do Paraitinga e Folia da Ponte Alta.

As nuvens voltaram e, desta vez, com uma forte chuva. O pessoal presente na festa se apinhou embaixo do rancho ou no interior da casa. A água tomou conta do terreiro que, apesar dos esforços dos filhos de seu João em esparramar areia, manteve-se enlameado até o final da noite.

Depois de muita lamentação, o fim da chuva, às 18 horas, deixou o tempo livre para as Folias, que começaram a se preparar. As Folias de fora do lugar se apresentaram no presépio montado na sala da casa. As duas primeiras se apresentaram uniformizadas, enquanto a terceira se apresentou com três foliões vestidos de Reis Magos. Apresentações curtas, que só justificaram a vinda das Folias para abrilhantar a festa. Mais à noite, elas acompanhariam o ritual da Folia mineira, apresentando-se novamente logo em seguida.

Após a apresentação, algumas senhoras vindas de Taubaté se colocaram ao lado do presépio, para serem fotografadas ou filmadas pelos familiares. Lembranças da presença e do acompanhamento do ritual religioso.

Aos poucos, saíram todas as pessoas da sala para o rancho. Entraram, alternadamente, os Foliões de Reis do bairro, que começaram a afinar os instrumentos. Eles iriam sair para cantar em duas casas próximas, para depois voltarem e realizar o ritual tradicional da Folia mineira.

A Folia saiu para as casas às $18 \mathrm{~h} 30$, com a promessa de chegar às 20 horas. Nesse intervalo, as músicas dos jovens tomaram conta da festa. Somente a visita de um deputado estadual eleito pela região deu um tom diferente à movimentação das pessoas. Ele foi ciceroneado por Ditão que, ao me cumprimentar, disse que não sairia de palhaço naquele ano, para acompanhar o deputado.

Entre doces, truco, música e cerveja, a festa começou a ficar cheia. No pequeno espaço que sobrava fora do rancho ou da estrada que leva ao sítio de João Santos, os carros amontoavam-se, atrapalhando a circulação das pessoas.

As pessoas que chegavam cumpriam regularmente um mesmo itinerário: entravam na casa para cumprimentar os festeiros e seus familiares, passavam pela bandeira exposta na parede de fora, comentando os 
versos grafados no pano"1 ou a foto com os "foliões antigos"12, e seguiam se enturmando com amigos e parentes pelo rancho, para comer doces, beber ou conversar.

Quando faltava pouco para as 20 horas, os grupos de Folia visitantes começaram a se encaminhar para a entrada do sítio, onde foi formado o primeiro arco, para esperarem a Folia local. Todos colocados no lugar, os foliões violeiros começavam, aos poucos, a tocar modas sertanejas, atraindo alguns sujeitos e transferindo, ou ampliando, os lugares da festa ${ }^{13}$.

A Folia chegou às $20 \mathrm{~h} 30$ e fez a primeira parada, cantando a entrada. Neste arco, um cartaz colocado por uma filha de seu João Santos desapareceu, talvez por causa da chuva.

Terminada a cantoria de entrada, a Folia passou pelo segundo arco e caminhou até o terceiro, seguida das demais, onde parou e cantou o fim de um ciclo de peregrinação, além de uma louvação a uma pintura do nascimento de Jesus, pendurada entre as folhas do bambu.

Seguindo até a casa, a Folia entrou na sala e começou e cantar no presépio. Os foliões estavam todos uniformizados, o que não era costume entre os membros da Folia antiga. Nos anos anteriores de retomada da Folia, nem mesmo os foliões novos tinham uniformes.

Após a cantoria do presépio, o mestre começou a cantar versos em memória dos foliões já falecidos, exaltando a tradição da festa e sua preservação. Havia uma emoção generalizada entre os diversos parentes e amigos espremidos na sala e surgiu, trazida de fora, a foto com a Folia antiga. Tonhão, marido de uma das filhas de seu Zé Leite, ficou segurando o quadro durante a apresentação. O clima de veneração da tradição se completou. A foto da Folia antiga tornou-se um ícone que rivalizava, no espaço da sala, com a bandeira da Folia ${ }^{14}$.

Encerrada a cantoria, todos saíram e começaram a preparar a cerimônia de passagem da coroa dos Reis velhos aos novos (antigos e novos festeiros).

Contrariamente aos anos passados e seguindo a tradição, os Reis Novos foram representados por um casal de filhos dos novos festeiros. A cerimônia foi realizada na frente da casa, aproveitando a altura elevada da calçada que levava à porta da sala, onde ficaram também os palhaços e os festeiros. Os versos seguiam o roteiro das fitas gravadas, já bem decorados pelo novo mestre, que se arriscava de vez em quando em um improviso. Aqui, como no presépio, seus improvisos eram versos cantados em veneração dos antigos foliões e da tradição da Festa de Santos Reis.

Este ano, somente a viúva de seu João Leite estava presente, entre as matriarcas do bairro. Porém, os novos festeiros foram justamente os Leite, que prometeram uma boa festa em 2002.

Encerrada a cerimônia, Sônia, filha de seu João Santos, tomou o microfone e começou a declamar um poema longo em homenagem aos foliões falecidos e à tradição da festa, exaltando a missão dos novos foliões. Seu discurso sintetizou bem as análises aqui elaboradas, explicitando os aspectos centrais reproduzidos em torno da retomada do ciclo festivo devocional, que coloco em destaque.

"Homenagem à Folia de Reis. Já faz muito tempo, foi lançada uma sementinha no grande jardim da vida, sendo regada. Cuidada, esta semente nasceu, fecundou suas raízes ao chão e foi crescendo, tornou-se um lindo botão. Ao seu lado foram surgindo lindos cravos unindo todos para uma missão encantadora: levar até nossas casas a história de um menino que nasceu na manjedoura. Viajando por muitos lugares em forma de verso e cançóes. Contava para o mundo, encantando corações o grande mestre e senhor que com todo o seu amor ia de improviso 
formando frases simples em bela mensagem de otimismo. Por muitos anos, em muitos anos percorrendo os caminhos, tirando choro e emoção. Na tristeza e na alegria com toda harmonia trazia para todo o povo baseada na história da Bíblia o grande salvador desta nação. Mas como nada é imortal na vida e tudo acaba, o grande criador do mundo foi aos poucos do convívio chamando estes cravos para viverem no seu reino, deixando assim no terreiro tristeza e lamentação, deixando um grande vazio e tristeza no coração. Silêncio foi se formando, aos pouco foi acabando este grupo de amigos que na simplicidade vivia trazendo paz, alegria, amizade e simpatia. Espalhavam na multidão neste jardim, só se via dor, onde havia só amor.

A saudade era presente, mas, como a vida não pode parar, deixando as mágoas pra lá, precisava continuar levando aos corações a paz entre nações, que acaba de achar no grande jardim da vida outra sementinha brotando lá no fundo e querendo germinar. A terra foi cuidada e muito bem regada e desta semente surgiu e o povo aplaudiu o renascer destas plantinhas, que cercadas de carinho vão percorrendo os caminhos e levando esta mensagem aos corações dos meninos, senhoras e senhores. Quero ver segurar agora o sucesso que vem surgindo estes novos amigos que das cinzas ressurgiram para nossa alegria, consigam por muito tempo transformar simples frases em canções de improviso para saudar o rei do mundo, homenageando os antigos que no céu estão unidos para vibrar com emoção os novos amigos e de todo coração trazer até nossos lares a história da libertação.

Com grande saudade eu digo: quem concordar comigo que em memória aos antigos peço agora uma saudação, que aplaudam estes cravos que no mundo onde estão agora sejam luz e inspiração aos novos e que a partir de agora seus caminhos seguirão. Com certeza, no coração a saudade vai ficar, com todos aqui presentes, que nas minhas palavras peço humildimente (sic) para estes amigos ausentes um pai nosso a rezar.

Esta luz que acendo agora, peço a Deus e Nossa Senhora que iluminem este grupo, que do seu silêncio profundo, a saudade neste mundo machuca e devora, mas que prossiga em frente, mostrando a nossa gente que tradição re vigora.

Salve os foliões antigos e amigos. Salve o mestre e seus amigos (foliões). Que em nossos corações sempre fique guardada a emoção do renascimento. Salve o grande João dos Santos e que a sagrada família lhe cubra com o seu manto".

Após seu "discurso", a parte religiosa da festa foi oficialmente encerrada e voltou a profana. Todo o lugar agora era do povo ali presente.

\section{ANOTACÕES CONCLUSIVAS}

I. A descrição dos eventos da festa de Santos Reis, em 2001, evidencia a solução dada ao desenvolvimento desse conjunto de relações, no qual a reprodução do modelo devocional tradicional implicou uma reconstrução gradativa dos traços que constituem a centralidade da vida comunitária. Desde a retomada da festa explicitaramse os movimentos identitários que os sujeitos negociam entre si e com outros sujeitos, em torno da manutenção de uma devoção local.

Se a festa acontece de uma outra forma, hoje, é porque a escala das relações entre identidade, cultura e lugar sofreu transformações profundas e, com elas, a própria devoção.

De qualquer modo, vimos que o fim da festa é relativo. O período de transição entre o encerramento da festa e sua retomada mostrou que ocorreu uma liminaridade no evento devocional. E não será a primeira vez que uma festa troca de protagonistas, passando de mãos do centro para a periferia. Paralelamente, supomos que será mais fácil que, na Semana Santa, desapareça o Cristo que o Judas. Afinal, no caso aqui estudado, o 
palhaço, a máscara, como o Judas e outros personagens, são mais "simples", "elementares" ou "primitivos" que as outras figuras, e por isso é mais fácil que sobrevivam, reformando o ciclo festivo devocional ao seu redor, que passa a se expressar mais ou menos espetacularizado, ou performático.

A perda dos antigos foliões (sobretudo Mestre Adolfo) é importante para o entendimento dessa mudança, uma vez que eles eram os detentores das grandes narrativas que sustentavam o modelo devocional tradicional. Como, entre os mestres de outras Folias locais, não havia sujeitos legitimados para a reprodução do ritual central da devoção, os jovens organizadores da festa tiveram que buscar em fontes diversas os instrumentos que permitiram sua reconstituição.

Nessa transição, recorrer à fita gravada com o ritual da Folia implicou um conjunto de outros procedimentos necessários para a realização da festa, que forçou os organizadores a negociarem e incluírem atores externos à comunidade, que influenciaram e "modernizaram" o ciclo festivo devocional.

São exemplos dessas negociações, na festa de 1999, a busca de apoios financeiros para a contratação do equipamento de som e a confecção de cartazes; o deslocamento do lugar da festa; a participação de outra Folia de Reis; a presença de fotógrafos; a arrecadação de gêneros para a confecção dos doces; a autorização para barracas de ambulantes; a montagem de um bar para venda de cerveja e a participação de agentes culturais da Prefeitura local.

Esses novos atores estruturaram-se na seqüência das festas, resultando em mudanças na estrutura do próprio ritual devocional, no qual os foliões do bairro passaram a apresentar-se uniformizados, além do novo Mestre incluir versos sobre a "antiga" Folia no seu repertório. Ou seja, os atores se assumiram como "entidades liminares" (Silva 2005), nesse processo.

Além dessas características centrais, as atividades extensivas ao ritual passaram a incluir, definitivamente, a presença de outras Folias, coadjuvantes na manifestação, mas suas legitimadoras, como o coro, no teatro, que legitima os protagonistas; os arcos por onde a Folia passava eram ornamentados com iconografias; o presépio montado na casa da festa e a bandeira da Folia transformaram-se em ícones, atraindo sujeitos de fora para fotografar suas presenças no evento (como ocorre nos centros de peregrinação de turismo religioso); a confecção dos adereços dos foliões e dos palhaços passa a ser feita, de forma artesanal, à vista dos visitantes; bandeiras e máscaras produzidas por artistas, a pedido de agentes culturais da prefeitura, passam a ser exibidas em arranjos ornamentais no espaço da festa; o ritual da passagem da coroa dos festeiros passa a ser amplificado por equipamento de som, para que toda "a assistência" possa ouvir bem a cantoria dos foliões e a ordem de apresentação dos personagens do ritual passa a seguir um roteiro rígido, como em uma encenação teatral.

Esses novos condicionamentos culturais explicitam um marco expressivo na transformação de uma festa "tradicional" em uma festa "tradicionalista" - Hobsbawn e Ranger (1984) já afirmaram que a tradição é uma questão de comunicação, enquanto o tradicionalismo é uma questão de ideologia. Via de regra, os tradicionalismos são obras de populações urbanas (o que está sugerido no caso do ciclo festivo devocional do bairro da Santa Cruz), que encampam alguma tradição rural morta ou moribunda.

Nesse sentido, os familiares que incentivaram a retomada da Festa de Santos Reis, assim como os sujeitos que se responsabilizaram pela sua organização, encenavam um auto de tombamento. E aqui um outro elemento 
emerge. Em outros tempos, o registro do "tradicional" - em relatos e partituras - era privilégio de classes letradas; agora, a popularização do registro em meios eletrônicos gera uma situação nova ${ }^{15}$. Entre outras coisas, é mais difícil a mudança "inocente", é mais difícil que as coisas mudem e continuem sendo "tradicionais", como sempre aconteceu, uma vez que agora os sujeitos detêm o registro para denunciar a mudança.

Desse prisma, o uso da tecnologia deslocou o sentido das estratégias identitárias, antes centradas em um enraizamento histórico que tinha dois vetores tradicionais: a memória e o(s) narrador(es).

Esse seria o sentido mais profundo da influência da tecnologia nas culturas tradicionais, como afirma Postman (1994: 29):

(...) "as novas tecnologias alteram a estrutura de nossos interesses: as coisas sobre as quais pensamos. Alteram o caráter de nossos símbolos: as coisas que pensamos. E alteram a natureza da comunidade: a arena na qual os pensamentos se desenvolvem" (itálicos no original).

Porém, se a perda dos narradores tradicionais implicou a necessidade de produzir novas mediações, o uso da tecnologia, além de alterar a estrutura, o caráter e a arena das relações culturais tradicionais, cumpriu também o papel estratégico de reconstituir os fragmentos da narrativa (do ritual), que assim foram "congelados" (Martins 2002) em um primeiro momento. Isso fez com que a memória coletiva do evento, colocada em suspensão, pudesse ser retomada e ressignificada em sínteses múltiplas, negociadas coletivamente. Entretanto, a tecnologia também auxiliou a transformar a atividade devocional em um "espetáculo", tornando constante e necessária sua própria utilização posterior. Nesse sentido, o recurso da tecnologia produziu o que denomino uma hipérbole da performance.

Assim, uma contradição se instalou na manifestação, pelo uso da tecnologia, que precisou ser retrabalhada nas festas posteriores. As interlocuções e trocas simbólicas que se seguiram, então, entre os condicionantes próprios da comunidade e as influências exteriores, definiram-se em situações nas quais se solucionaram os procedimentos que "descongelaram" a narrativa ritual.

Nesse processo, o peso do imaginário local, contido na narrativa ritual que a tecnologia aprisionou, teve de ser superado pela construção de uma narrativa equivalente (ao menos, para a comunidade) onde novos imaginários emergiram, atualizando o sentido da devoção.

II. Os relatos e as análises aqui elaborados remetem a questionamentos sobre as imbricações entre a duração dos ciclos festivos devocionais e a relação dual processo ritual-estrutura social. Sobretudo, evidencia-se nessas descrições que "a hierarquia dos valores ligados às diversas atividades sociais (...) traduzem o papel dominante no seio da sociedade de certas estruturas sociais" (Godelier 1974: 79) - no caso, as relações de parentesco e a religião - e que a transição do controle ritual depende da produção de uma condição de "liminaridade" (Turner 1974). Nessa condição, o conhecimento tradicional de um grupo é avaliado, incorporado e "reativado" sob novas perspectivas sociais.

E aqui, a análise que Martins elabora sobre o "modo de produção de imagens fotográficas" (2002: 224) pode elucidar mais os termos propostos: 
“O chamado 'congelamento' do instante fotográfico é, na verdade, a redução das desencontradas temporalidades contidas nos diferentes componentes da composição fotográfica a um único e peculiar tempo, o tempo da fotografia.

É nessa construção, nessa redução dos tempos da realidade social ao espaço da imagem fotográfica e ao seu tempo aparentemente único, que o fotógrafo imagina, isto é, constrói a sua imagem fotográfica, aquilo que quer dizer através da fotografia. (...) O 'congelar' não é mais do que o sublinhar elementos de referência de um imaginário cujo âmbito não se restringe ao reducionismo dos supostos 'congelamentos'. O pressuposto de que a fotografia é um ato de 'congelamento' não é mais do que a ideologia do ato fotográfico, algo bem distante da apreciação propriamente científica do que é a fotografia.

Os fotografados também imaginam e se imaginam, e são agentes e personificações das estruturas e dos processos sociais de que têm apenas uma compreensão imaginária ou, simplesmente, ideológica" (idem: 224).

Ora, substituindo contextualmente o termo fotografia, e seus correlatos, pelo termo tecnologia, e seus correlatos, a análise acima corresponde profundamente com as análises aqui desenvolvidas.

Sobretudo, importa reconhecer que os sujeitos envolvidos na reconstituição da festa imaginam e se imaginam, no quadro de estruturas e processos sociais. Assim, a utilização da tecnologia deve ser aqui situada

“(...) como instrumento da interação imaginária com os ausentes (e com os mortos) [e] se constitui num meio essencial de sustentação da sobrevida dos mortos, da continuidade imaginária das relações sociais mesmo depois da morte. Por esse meio, fala-nos da comunidade imaginária que se sobrepõe à mortalidade física do contemporâneo.

E dos vivos que [a tecnologia] quer falar, mesmo quando fala de mortes culturais e simbólicas. Ou quando nos fala de um sagrado cercado, ameaçado de corrosóes de todo tipo, mas que, no entanto, persiste, se renova, até mesmo incorporando a [tecnologia] que o condena" (idem: 237).

Trata-se de perceber, então, que essa incorporação detona uma estratégia de empreendimento cultural local, onde os novos organizadores do ciclo festivo devocional "colocam-se localmente como mediadores entre escalas, o que implica competências de tradução, lingüística e cultural, e de acessibilidade, por ativação de redes sociais e políticas de alcance extralocal" (Agier 2001: 19).

Essas competências expostas por Agier são aqui estruturadas no desenvolvimento de um processo de reflexividade "performático-identitária", operado pelos atores locais que se intencionam como mediadores. Assim, as lacunas percebidas na narrativa ritual gravada e exposta na festa de 1999 seriam posterior e gradualmente preenchidas por atores diversos que participaram da reconstituição da tradição, "obrigados a conceber e colocar sua criação nesse quadro a título, por exemplo, da cor local (...)" (idem: 21).

Dessa perspectiva, a liminaridade operada no ritual devocional, aqui esboçada, ou ao menos a produção de uma equivalência da tradição devocional com uma tradição construída no processo de reconstituição daquela, foi operada por uma "seleção situacional" (Evans-Pritchard apud Agier 2001: 12), na qual os traços constitutivos da cultura do grupo expressavam-se como sua crença (Lopes 1995).

Essa expressão está sintetizada nas justificativas dos jovens organizadores das festas de 1999 e 2001. Tratava-se, ali, da afirmação de uma "cultura identitária" (Agier 2001: 22), fabricada na e sobre a performance dos atores envolvidos em uma devoção local. 
O longo poema escrito e declamado no final da festa de 2001 representou o clímax dessa liminaridae, onde os valores tradicionais foram metaforizados em uma pequena narrativa de dimensão épica e comunitária, cuja centralidade assentou-se nas figuras dos antigos e novos foliões. Os jogos de reconhecimento que se produziram em torno dessa centralidade devocional buscavam convergir os traços fragmentados pela dispersão da comunidade, para reconstitui-los sob novos condicionamentos culturais.

A retomada da plenitude do ciclo festivo devocional implicou declarar que a devoção continua viva - e com ela a comunidade e a cultura que a configuram. Assim, a cultura tornou-se declarativa para tornar-se "o argumento da declaração de identidade" (Agier 2001: 23).

Ocorre que os sujeitos explicitaram, nesse processo, que a continuidade da devoção, e a afirmação da memória e da identidade a ela relacionadas, podem significar também sua mudança, sua atualização. 


\section{NOTAS}

1 Este artigo é uma versão revista e ampliada da comunicação homônima apresentada no GT Ritos da Cultura Popular, durante a 25a Reunião Brasileira de Antropologia (ABA), realizada em Goiânia, em junho de 2006.

2 Seu Adolfo era o sujeito mais letrado entre os idosos do bairro, dono de uma grande criatividade, e advinha de uma "linhagem" de grandes Mestres de Folia de Minas Gerais, além de possuir uma capacidade de dar respostas para qualquer pergunta, refletindo por circunvolução (ver Lopes 1997). Seu Zé Leite era o sujeito que organizava as atividades comunitárias, como os contatos entre as famílias, as reuniões festivas e os tradicionais mutirões do bairro. Já seu Vicente era o Inspetor de Bairro, cargo atribuído ao mesmo pelas autoridades municipais locais. A reunião dos três sujeitos na Folia realizava, então, uma síntese das expressões comunitárias e familiares tecidas no bairro.

3 Embora essa afirmação diga respeito a uma observação de campo datada, é importante enfatizar que os estudos de festas rurais, no Brasil, têm evidenciado a autonomia popular frente à igreja paroquial (Brandão 1977 e 1981; Ribeiro Jr. 1982; Zaluar 1983). No caso etnográfico em questão, identifico e analiso mais de um fator de dispersão nas relações em desenvolvimento, em virtude de conjunturas históricas e contextuais observadas.

4 Numa festa de Reis é importante observar a ação dos palhaços que, em obediência às ordens do Mestre, procedem e manipulam o ritual da Folia: esmolam, brincam e assustam os presentes, protegem a Folia, coroam os festeiros e dançam. Sua movimentação, quando conformada ao ritual, torna-se ponto focal de todos e libera o mestre e sua Folia para se concentrarem na criação e no canto em devoção aos Santos Reis. Esse processo torna-se importante, aqui, por considerar que, nele, ocorre a "transmissão do conhecimento performático" (Schechner apud Silva 2005: 62) que será encenado pelo palhaço.

5 Diferenças entre as Folias de Reis mineira e paulista marcam-se pela composição do grupo de foliões, pelo ritual devocional, pela realização da festa e pela tradição dos Mestres de Folia (os dois últimos relativos ao caso da mineira) (Brandão 1996). O fato de Lúcia ter explicitado essa "exterioridade distinta" mostra que sua justificativa está carregada de um sentido estratégico de definição de um lugar próprio (Certeau 1993), mas também que o grupo devocional não reconhece ou considera como legítimos os intérpretes disponíveis.

6 Tradicionalmente, os palhaços teriam o papel, ou tarefa, de dramatizar as orientações cantadas pelo Mestre, enquanto os familiares seriam auxiliares na execução da infraestrutura da festa ou espectadores da mesma.

7 A concepção de "memória" será tratada, aqui, segundo sua configuração estabelecida desde Halbwachs (1990), como memória coletiva. Embora a discussão sobre os termos "memória local", "memória coletiva", "memória individual", "imaginário social", entre outros, atravesse um conjunto diversificado de autores, inclusive contemporâneos, essa discussão será tratada em uma ampliação posterior deste estudo. Por agora, destaco a elucidação que Halbwachs elabora sobre a atuação das lembranças na constituição da memória: o autor afirma que "elas devem concordar no essencial" (: 25), para que se constitua um fundamento comum, sobre o qual as próprias lembranças possam ser reproduzidas e recordadas (: 34$)$ num determinado grupo. É importante destacar também, para o caso analisado, que ele afirma que a reconstrução da memória implica uma operação "a partir de dados ou de noções comuns que se encontram tanto no nosso espírito como no dos outros" (: 34), tornando-as recíprocas. E porque trafegam na mão dupla das relações sociais, "nossos sentimentos e nossos pensamentos mais pessoais buscam sua fonte nos meios e nas circunstâncias sociais definidas" (: 36) por essas relações. É esse caráter situacional da memória que penso ser importante, aqui, para entender os movimentos e negociações que se operam entre os sujeitos da comunidade e entre estes e os agentes exteriores ao contexto local.

8 Toma-se a concepção de natureza em sua definição filosófica: “Para definir este termo [...] há alguns pontos em comum. Os principais são os seguintes: 1. princípio do movimento ou substância; 2. ordem necessária ou conexão causal; 3. exterioridade, contraposta à interioridade da consciência; 4. campo de encontro ou de unificação de certas técnicas de investigação" (Abbagnanno 2000: 699). Destaca-se, aqui, a concepção de Aristotéles do primeiro ponto, elaborada na sua Physis, de que "a Natureza é o princípio e a causa do movimento e do repouso da coisa à qual ela inere primariamente e por si, e não por acidente" (idem). Ou seja, a forma da manifestação preserva-se em sua substância, que tem o princípio do movimento em si própria. 
9 Entretanto, as mudanças ocorridas na festa, em função dessas novas negociações, já vinham sendo anunciadas há pelo menos seis anos, na festa de Santa Cruz, que a mesma comunidade promove. Essa abertura já ocorria pelo fato desta última festa sempre ser realizada na vila (em frente à capela do bairro), fugindo ao controle familiar que caracteriza a festa de Santos Reis.

10 Depois, ficamos sabendo que a bandeira exposta não era a da Folia. Esta outra bandeira e mais duas máscaras de palhaço foram doadas por agentes culturais da Prefeitura de São Luiz do Paraitinga. Mais sofisticadas que as máscaras simples e tradicionais da Folia mineira, foram deixadas somente como decoração, em proveito da utilização das antigas. Idem com a bandeira, que, além do mais, "está pintada num pano azul. A cor da bandeira de Reis é vermelha", afirmou-nos Dona Maria, esposa de seu João Santos.

11 "Cantamos com o coração e regozijo o nascimento de Jesus, com muita satisfação e respeito. No seu lar adentramos orando cantando a Ressurreição da Alegria".

12 Assim como nas Festas de Reis de 1999 e de 2000, a representação de Antigüidade atribuída aos foliões que inauguraram a festa no bairro era ali também reproduzida. Estava em jogo, aqui, a construção de um mito (ou uma tradição) em torno desses sujeitos, que objetivava claramente a manutenção da tradição da festa (mas também criava um paralelismo com a mesma) e a preservação das relações familiares mantidas por aqueles patriarcas. Essa pretensão ficou explícita em 1999, quando, ao som de uma fita gravada da Folia, cantada por Mestre Adolfo Leite, Ditão conduziu a cerimônia do passamento da coroa, enfatizando a presença das viúvas de seu Zé Leite e seu João Leite, ladeadas pelas filhas.

13 Os lugares da festa eram muitos e móveis. Com exceção do rancho e da casa, além dos arcos - estes compõem lugares do ritual da Folia -, os demais lugares variavam com as relações que se estabeleciam no evento. Assim, os lugares móveis faziam com que a festa se tornasse flexível, como território. Os diversos lugares produzidos pelos agrupamentos de jovens, durante o período da festa, eram exemplares, nesse sentido. No caso do sítio de seu João Santos, devido ao pouco espaço, tais lugares gravitavam próximos ao centro: a casa e o rancho.

14 Há que se ressaltar que a mesma foto, antes exposta no rancho fora da casa da festa, já produzia uma equivalência de venerações com a Bandeira de Reis que estava ao seu lado.

15 Quatro tecnologias de registro da memória foram amplamente difundidas nas camadas populares, na segunda metade do século XX: o gravador portátil, a câmera fotográfica e, mais recentemente, a câmera de vídeo (VHS ou digital) e os celulares com câmera digital. As possibilidades de registro que se combinam no uso contínuo ou regular dessas tecnologias, pelos sujeitos, podem ser constatadas em vários eventos sociais. Assim ocorre também nas festas religiosas tradicionais. Nos últimos dez anos, tenho observado o uso crescente de máquinas fotográficas e gravadores pelos sujeitos da região, documentando diversos aspectos dessas festas locais, para fins também diversos. Deve-se enfatizar, aqui, que o constante assédio de cientistas sociais e repórteres nessas manifestações muito contribuiu para disseminar esse "novo costume". No entanto, a importância dessa referência para a ampliação do campo de opções metodológicas na investigação empírica, o que interfere decisivamente na maneira como a antropologia registra tais eventos, ainda não recebeu o tratamento adequado. 


\section{REFERÊNCIAS BIBLIOGRÁFICAS}

ABBAGNANNO, Nicola. 2000. Dicionário de Filosofia. São Paulo: Martins Fontes.

AGIER, Michel. 2001. “Distúrbios Identitários em Tempos de Globalização". Mana 7(2): 7-33.

BRANDÃO, Carlos R. 1977. "A Folia de Reis de Mossâmedes". Cadernos de Folclore 20. Rio de Janeiro: CDFB/ FUNARTE.

Vozes.

. 1981. Sacerdotes de Viola. Rituais religiosos do catolicismo popular em São Paulo e Minas Gerais. Petrópolis:

1996. A Partilha da Vida. Taubaté: Cabral.

CASTRO, Zaíde Maciel de. 1977. Folia de Reis. Cadernos de Folclore 16. Rio de Janeiro: CDFB/Funarte.

CERTEAU, Michel de. 1993. A Invenção do Cotidiano (Artes de fazer). Petrópolis: Vozes.

GODELIER, Maurice. 1974. "Hierarquias nas Sociedades Primitivas e Antropologia Econômica”. In Neuma Aguiar (org.) Hierarquia em Classes. Rio de Janeiro: Zahar.

HALBWACHS, Maurice. 1990. A Memória Coletiva. São Paulo: Vértice.

HOBSBAWM, Eric e Terence Ranger (orgs.). 1984. A Invenção das Tradições. Rio de Janeiro: Paz e Terra.

LOPES, J. Rogério. 1991. Vida Mineira no Eito Paulista: produção de sentido e dinâmica do saber no cotidiano popular. Dissertação de Mestrado em Ciências Sociais. São Paulo: PUC.

. 1995. A Cultura como Crença. Estratégias modernas de reprodução da vida popular. São Paulo: Robe/Cabral.

. 1997. “Das Maneiras de Conhecer: as atribuições da educação na memória de um camponês”. Revista da Unitau

- Humanas 3(2): 41-49. Taubaté: PRPPG/Unitau.

LOPES, J. Rogério e Marcelo H. Santos Toledo. 1994. "Migração Mineira no Alto Vale do Paraíba, SP". Anais do XII Simpósio de História do Vale do Paraíba. Univap/IEV.

MARTINS, José de Souza. 2002. A Imagem Incomum: a fotografia dos atos de fé no Brasil. Estudos Avançados 16(45): 223-260. São Paulo: IEA/USP.

ORTIZ, Renato. 1980. Religiões Populares e Indústria Cultural. Religião e Sociedade 5: 51-63. Rio de Janeiro: CER/ISER/ Tempo e Presença.

POSTMAN, Neil. 1994. Tecnopólio - a rendição da cultura à tecnologia. São Paulo: Nobel.

RIBEIRO Jr., Jorge C. N. 1982. A Festa do Povo. Petrópolis: Vozes.

SÀEZ, Oscar Calavia. 1999. Deus e o Diabo em Terras Católicas (Brasil-Espanha). Taubaté: GEIC/NIPPC.

SILVA, Rubens Alves da. 2005. Entre "Artes" e "Ciências": a noção de performance e drama no campo das ciências sociais. Horizontes Antropológicos 74: 35-65, jul./dez.

TOFFLER, Alvin. 1965. O Povo e a Cultura. Rio de Janeiro: Lidador.

TOLEDO, Marcelo H. Santos. 2001. Espaços Individuais e Coletivos de Sacralidade nos Meios Populares. Um estudo sobre imagética, conflitos simbólicos e campo religioso. Dissertação de Mestrado em Ciências da Religião. São Paulo: PUC.

TURNER, Victor. 1974. O Processo Ritual: estrutura e anti-estrutura. Petrópolis: Vozes.

ZALUAR, Alba. 1983. Os Santos e suas Festas. Religião \& Sociedade 8: 53-60. 
Deus Salve Casa Santa, Morada de Foliões. Rito, Memória e Performance Identitária em uma Festa Rural no Estado de São Paulo

\section{RESUMO}

O texto analisa as mudanças ocorridas no ritual de devoção aos Santos Reis, em uma festa rural tradicional do município de São Luiz do Paraitinga, na região do Alto Vale do Paraíba (SP). A festa tem tradição de mais de quarenta anos, realizada em um bairro rural formado por migrantes mineiros. Por ocasião do falecimento dos "antigos foliões" do bairro, a festa deixa de ser realizada por dois anos, sendo retomada em 1999 por descendentes daqueles, sob novos condicionamentos culturais, como a utilização de meios eletrônicos e dramatizações que recorrem à memória dos antepassados. Essas novas mediações produzem gradativamente um ritual em memória dos antigos foliões em simultaneidade com o ritual devocional tradicional. Descreve-se historicamente a formação do bairro e expõe-se uma etnografia das mudanças recentes no ritual festivo, de forma a localizar os elementos tradicionais e de mudanças que interferem na continuidade do ritual, no meio rural, buscando reconhecer as novas mediações produzidas nas devoções populares.

PALAVRAS CHAVES: ritual, cultura popular, performance, memória, identidade.

'God Save Casa Santa, Morada de Folióes': rite, memory, and identity performance in a rural party (São Paulo, Brazil)

\section{ABSTRACT}

The text analyses the changes occurred in the ritual of devotion to the Three Wise Men from the East in a traditional countryside celebration in São Luiz do Paraitinga district, which is part of the Paraíba Highland Valley region, São Paulo state, Brazil. The celebration has a tradition that is more than 40 years old, and it takes place in a countryside district formed by migrants from Minas Gerais state. After the death of the "former buffoons" that lived in the district, the celebration did not take place for two years, but was restarted in 1999 by their descendents, now under new cultural concepts, such as the use of electronic paraphernalia and dramatization built upon their ancestors' memory. These new mediations produce, little by little, a ritual in memory of the old buffoons which integrates the traditional devotional ritual. The historical development of the district and the celebration are described here in order to point out the traditional elements and the changes that interfere with the continuity of the ritual, in the countryside, aiming to identify their impacts on the popular devotion.

KEYWORDS: ritual, popular culture, performance, memory, identity.

Recebido em 23/06/2006

Aprovado em 05/04/2007 